\title{
Prenatal developmental changes in glucose transporters, intermediary metabolism and hormonal receptors related to the IGF/insulin-glucose axis in the heart and adipose tissue of bovines
}

\author{
Jean-François HocQuetTE ${ }^{\text {a*}}$, Helga SAUERWEIN ${ }^{\mathrm{b}}$, Yumi HigaSHIYAMA ${ }^{\mathrm{c}}$, \\ Brigitte PICARD ${ }^{\mathrm{a}}$, Hiroyuki ABE ${ }^{\mathrm{d}}$ \\ ${ }^{\text {a }}$ INRA, Herbivore Research Unit, Muscle Growth and Metabolism Team, Theix, \\ 63122 Saint-Genès-Champanelle, France \\ ${ }^{\mathrm{b}}$ Institute for Animal Sciences, Physiology and Hygiene Group, University of Bonn, \\ 53115 Bonn, Germany \\ ${ }^{c}$ Pasture and Grazing Management Laboratory, National Agricultural Research Centre for Tohoku \\ Region, Akahira 4, Shimo-kuriyagawa, Morioka, Iwate, 020-0198, Japan \\ d National Institute of Livestock and Grassland Science, Ikenodai-2, Tsukuba, Ibaraki, 305-0901 Japan
}

(Received 7 November 2005; accepted 28 February 2006)

\begin{abstract}
Glucose transporter ontogenesis is likely to play a key role in glucose uptake by foetal tissues in order to satisfy their energy requirements. We thus investigated developmental changes in the bovine heart and perirenal adipose tissue in two glucose transporter isoforms, namely GLUT1 and GLUT4, the latter being responsible for the regulation of glucose uptake by insulin. Other key players of the glucose/insulin axis were also assessed. Plasma glucose concentration in the foetus was lower at 8 and 8.5 months of age than previously. In the heart, GLUT1 protein level markedly decreased between 3 and 4 months of age, whereas the number of insulin and IGF-I binding sites continually decreased, especially between 7 and 8 or 8.5 months of age. On the contrary, the GLUT4 level increased until 8 months of age and remained high until 2 weeks after birth. The activities of enzymes of glucose metabolism (namely phosphofructokinase [PFK] and lactate dehydrogenase $[\mathrm{LDH}]$ ) increased throughout gestation and reached a plateau at 6 and 8.5 months of age for PFK and $\mathrm{LDH}$, respectively. The activities of enzymes involved in fatty acid metabolism increased especially at birth. In perirenal adipose tissue, high mitochondrial activity was detected before birth which is a characteristic of brown adipose tissue. Furthermore, lipoprotein lipase activity and GLUT4 protein level markedly increased to reach a maximum at 6-7 and 8 months of age, and sharply decreased thereafter, whereas GLUT1 protein level increased between 6 and 7 months of age. In conclusion, considerable changes in the regulation of the insulin/glucose axis were observed from 6 months onwards of foetal development in both the heart and adipose tissue of cattle, which probably alters the potential of these tissues to use glucose or fat as energy sources.
\end{abstract}

glucose transporter / heart / adipose tissue / bovine / foetal development

\footnotetext{
*Corresponding author: hocquet@clermont.inra.fr
} 


\section{INTRODUCTION}

More and more evidence suggests that body composition and metabolic characteristics of mammals (including farm animals, laboratory rodents and human beings) depend, to a great extent, on the nutritional events which occur before birth. As a consequence, the potential of human beings to develop certain metabolic diseases at the adult stage (such as noninsulin dependent diabetes mellitus, obesity or insulin resistance) or the potential of farm animals to develop a high muscle mass at the expense of fat for the production of lean meat may originate, at least in part, from malnutrition at critical phases during foetal development. This has led to the concept of "nutritional programming" which is now a subject of active investigation in both the fields of medical [1] and animal science [2]. The concept is based on the observations that undernutrition or over-nutrition, at a critical period of foetal development, has a long term outcome during postnatal life [3]. This new idea leads the way for a significant manipulation of body composition and health before birth by adequate nutrition of the foetus. For the heart, cardiovascular diseases may also be partly programmed during intrauterine growth $[1,3]$. Furthermore, low birth weight has been associated with an increased incidence of ischemia [4] or cardiovascular diseases [5]. The challenge is, nowadays, to understand the basic biological mechanisms which control tissue differentiation and how they are regulated by nutritional factors. It has been suggested that IGF-I may serve as a link between foetal growth and cardiovascular disease [4]. Furthermore, specific studies have been carried out on the insulinglucose axis which is of major importance for the control of body composition and insulin sensitivity and hence for the incidence of diabetes $[6,7]$.
Glucose is cleared from the bloodstream by a family of glucose transporters (GLUT) which catalyse the transport of glucose down its concentration gradient and into cells of target tissues. Several GLUT isoforms have been characterised, among them GLUT1 expressed in many tissues and especially erythrocytes, GLUT2 expressed in the liver and GLUT4 expressed in insulin-sensitive tissues (heart/muscle/fat) only. Heart, skeletal muscle and adipose tissue are of great physiological interest due to the regulation of their glucose transport rate by insulin $[8,9]$. This allows a regulation of glucose tolerance at the whole body level. More than twenty years ago, it was shown that recruitment following insulin stimulation of GLUT4 from intracellular membranes is the key point of regulation of glucose metabolism by insulin [6]. Any dysregulation in this process may permanently affect body composition, induce insulin resistance and be the origin of the above-mentioned physiological metabolic disorders (cardiovascular diseases, obesity or diabetes) [9]. Furthermore, any disturbance in the foetal ontogenesis of GLUT4 and any other proteins related to glucose metabolism and insulin action may accentuate the susceptibility of mammals to develop these metabolic problems later on at the adult stage. Precise knowledge of the different steps of metabolic differentiation of insulin-sensitive tissues is thus required.

Several studies have been conducted to describe the metabolic differentiation of the heart, skeletal muscles and adipose tissues, but most often in laboratory rodents [10-12]. Unfortunately, the short period of gestation of rodents does not provide a clear picture of the chronological sequence of tissue differentiation. This is the reason why more recent studies have been conducted in cattle which are characterised by a gestation length similar to that of human beings (i.e. 9 months). Moreover, the degree of maturity for muscle development 
at birth is similar in humans and bovines, but higher than for other mammals such as pigs [13]. The mechanism of insulin action in bovines is also similar to that in other species, although dietary supply of glucose is very low in ruminants after weaning, thereby modifying insulin secretion and action [8, 14]. The insulin-sensitive glucose transporter GLUT4 was characterised in cattle by Hocquette et al. [15] and Abe et al. [16] at protein and mRNA levels respectively. Finally, foetal tissue samples are obviously easier to obtain in cattle than in laboratory rodents or humans. All these physiological and practical aspects make the bovine species a good model for developmental studies with potential interest for all mammals, including humans.

The objective of this study was thus to describe the ontogenesis of glucose transporters, insulin and IGF-I receptors and metabolic enzymes in two relevant tissues for major metabolic disorders: the heart and the adipose tissue which play key roles in the development of cardiovascular diseases and obesity/diabetes, respectively.

\section{MATERIALS AND METHODS}

\subsection{Reagents}

A polyclonal antibody was raised against bovine GLUT4 in rabbits. The synthetic peptide, to which the antibody was raised, was prepared by Neosystem Laboratoire (Strasbourg, France). It corresponds to the C-terminal part of the molecule as described for the antibody raised against rat GLUT4 [17]. A polyclonal antibody against bovine GLUT1 was supplied by Calbiochem (Southbridge, MA, USA). The chemicals for immunoblotting were supplied by Bio-Rad (Munich, Germany), except the membranes (Immobilon-P) which were obtained from Millipore (Bedford, MA, USA). ECL Western blotting kit and Hyperfilms MP were supplied by Amersham International (Amersham, Bucks,
$\mathrm{UK})$. Other reagents were from Sigma ( $\mathrm{St}$ Louis, MO, USA).

\subsection{Animals and tissue samples}

The study was carried out as part of a research programme approved by the "Institut National de la Recherche Agronomique" (INRA, France) Ethical Committee. The study included a maximum of 84 foetuses of comparable chronological age collected at $110,180,210$ or 260 days of gestation. The animals were from different breeds: Holstein $(n=25$ to 30) and Charolais of four different genotypes ( $n=13$ to 17 each). Six 15-dayold Montbeliard calves were also used. The cows were bred and slaughtered and foetuses were collected according to ethical guidelines concerning animal care. Calves were slaughtered after an overnight fast by stunning (captive-bolt pistol) and exsanguination. Blood samples were taken from foetuses for the determination of plasma glucose concentration according to the method previously described [18]. Heart and adipose tissue samples were collected at slaughter, snap-frozen in liquid nitrogen, and stored at $-80{ }^{\circ} \mathrm{C}$ until they were analysed. Since the animals were slaughtered in different locations and over successive years, not enough samples were taken for all analyses, especially at the youngest ages where the foetuses were very small.

\subsection{Preparation of subcellular fractions}

Heart and adipose tissue samples were homogenised at $4{ }^{\circ} \mathrm{C}$ in 8 volumes of a buffer containing $0.25 \mathrm{M}$ sucrose, $1 \mathrm{mM}$ EDTA and $10 \mathrm{mM}$ Tris- $\mathrm{HCl}(\mathrm{pH} \mathrm{7.4)}$ to which $1 \mathrm{mM}$ of PMSF, and inhibitors of various proteases were added as previously described [15]. Subcellular fractions were then prepared from tissue heart homogenates by differential centrifugation in 
order to separate nuclei, membrane proteins within microsomes and soluble proteins within the cytosol. All fractions were kept frozen at $-80^{\circ} \mathrm{C}$ until further use. Protein concentrations in whole homogenates and in the different subcellular fractions were determined according to the procedure of Bradford [19] before any other assays. The subcellular fraction, rich in membranes, was used for quantification of glucose transporters (GLUT4) by immunoblotting.

\subsection{Quantification of GLUT4 protein by immunoblotting}

The samples $(100 \mu \mathrm{g}$ of microsomal protein) were not routinely heated before electrophoresis to avoid the formation of aggregates, but incubated at room temperature overnight in Laemmli buffer containing 2-mercaptoethanol $\left(50 \mathrm{ml} \cdot \mathrm{L}^{-1}\right)$ to solubilise all the proteins. The samples were then subjected to SDS-PAGE on $12 \%$ acrylamide gels. Immunoblot was performed using polyclonal antibody against bovine GLUT4 or bovine GLUT1 (final dilution: $1 / 2000)$ as described [15]. GLUT proteins were detected using a horseradish peroxidase-labelled second antibody and a chemiluminescent reaction (ECL Western blotting kit from Amersham International). Hyperfilms MP were exposed to the membranes, and GLUT4 was quantified by scanning densitometry (Hoeffer, San Francisco, Hoeffer, USA) of the autoradiograms. The results were expressed in arbitrary densitometric units.

\subsection{Determination of biochemical characteristics and metabolic activities of tissues}

The biochemical characteristics of the tissues which were determined were total DNA and protein contents. Mitochon- drial activity was assessed by determination of isocitrate dehydrogenase (ICDH) and citrate synthase (CS) activities, two enzymes of the Krebs Cycle. The glycolytic metabolism was assessed by determination of lactate dehydrogenase (LDH) and phosphofructokinase (PFK) activities. The methods used were spectrophometric techniques which have been previously described by Ortigues-Marty et al. [20] and Cassar-Malek et al. [21]. Lipoprotein lipase (LPL) activity was assessed as previously described [22]. Rat serum was used as the activator and $\left[{ }^{3} \mathrm{H}\right]$-triolein labelled Intralipid $^{\circledR}$ (Pharmacia, Stockholm, Sweden) was used as the substrate to ensure maximum activity. Maximum enzyme activities were expressed in micromoles of substrate consumed or in micromoles of product released per $\mathrm{g}$ fresh tissue.

\subsection{Determination of insulin and IGF-I binding sites}

An enzyme immunoreceptor assay (EIRA), which allows for the determination of both affinity and capacity of the receptors, and described in detail by Boge et al. [23] was used. Membrane preparation and solubilisation of receptors were performed according to Einarson [24]. In brief, solubilised receptors were immobilised onto microtitre plates using receptor specific monoclonal antibodies that recognise the intracellular $\beta$-domain of the respective receptors (clone 17A3, kind donation of R.A. Roth, Stanford, California, USA and clone 29B4, Dianova Immunotech, Hamburg, Germany). After washing, the immobilised receptors were labelled with either biotinylated IGF-I or insulin in the presence or absence of varying amounts of unlabelled IGF-I (0.32 to $3.2 \mathrm{ng} /$ well) or insulin (0.5 to $5 \mathrm{ng} /$ well). Each sample measurement included six different hormone-biotin concentrations. Nonspecific binding of 
every sample was controlled by adding excess unlabelled IGF-I (100 ng) or insulin (200 ng). After incubation, the plates were decanted and the bound biotin was quantified using the streptavidin horseradish technique. For calibration of the assay, the absolute molar amount of receptor in a defined standard preparation was measured using ${ }^{125}$ I-labelled hormones and calculated by both Scatchard analysis [25] and Lineweaver-Burk plots. This standard receptor preparation was used for every microtitre plate EIRA. The amount and affinity of the receptors present in the unknown samples were calculated from the saturation curves which were linearised for the standard solubilisate by a double reciprocal plot according to Lineweaver-Burk. Using these data, the dissociation constant, $\mathrm{Kd}$, and the receptor concentration were calculated using the LIGAND programme [26]. The assay had a detection limit of 1 fmol receptor/well. The intraassay variation was $9 \%(n=22)$ for the IGF-I receptor concentration and $12 \%(n=22)$ for the insulin receptor. The interassay variation was $5 \%(n=4)$ for the IGF-I receptor and $10 \%(n=4)$ for the insulin receptor. The coefficient of variation of the dissociation constants $\left(K_{d}\right)$ was $26 \%(n=7)$ for the IGF-I receptor and $24 \%(n=7)$ for the insulin receptor.

\subsection{Statistical analysis}

Analysis of variance of the data was carried out using the general linear models procedure of SAS [27] with the genotype and age effects and the interaction between both effects. For glucose transporters, hormone binding sites and metabolic activities, the genetic effect and the interaction with age were not significant $(P>0.40)$ whereas the age effect was generally highly significant $(P<0.001)$. Differences between ages were tested using the StudentNewman-Keul test. $P<0.05$ and $P<$
PLASMA GLUCOSE CONCENTRATION

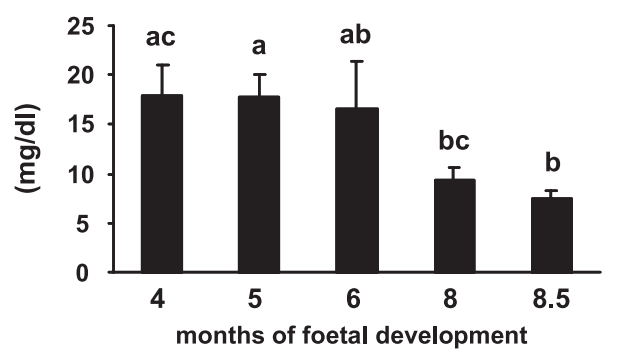

Figure 1. Plasma glucose concentrations in bovine foetuses throughout development. Means with different superscript letters differ significantly $(P<0.05)$.

0.10 were considered statistically significant and as a tendency for a statistical significance, respectively.

\section{RESULTS}

\subsection{Developmental changes in biochemical and metabolic characteristics of the heart}

The weight of the heart represented $0.7 \%$ of body weight irrespective of the age of the animals. Plasma glucose concentration decreased during foetal life: it was indeed higher from 4 to 6 months of age than thereafter (Fig. 1).

Total protein contents in heart homogenates were significantly higher in young calves than in 3 to 7-month-old foetuses $(+137 \%, P<0.05)$, with 8.5 -monthold foetuses having intermediate values (Tab. I). However, protein contents in microsomal membranes, which were used for glucose transporter studies, were the highest at 6 months of foetal age and the lowest in young or old foetuses as well as in calves (Tab. II). Total DNA content was significantly higher in 3 to 8-month-old foetuses than in 8.5-month-old foetuses and young calves $(+48 \%, P<0.05)$ (Tab. II). 
Table I. Developmental changes in total protein contents (mg per $\mathrm{g}$ fresh tissue) and in some enzyme activities $\left(\mu \mathrm{mol} \cdot \mathrm{min}^{-1}\right.$ per $\mathrm{g}$ tissue wet weight) in the bovine heart during foetal life.

\begin{tabular}{lcccccccccc}
\hline $\begin{array}{l}\text { Age in months (m) } \\
\text { before or after birth }\end{array}$ & $\begin{array}{c}\text { Number } \\
\text { of animals }\end{array}$ & 3 & 4 & $\begin{array}{c}5 \\
\text { post conception }\end{array}$ & 7 & 8.5 & $\begin{array}{c}0.5 \\
\text { after birth }\end{array}$ & SEM $^{*}$ \\
\hline Number of animals & & 15 & 5 to 18 & 6 to 10 & 7 to 12 & 6 to 10 & 7 to 14 & 4 to 6 & \\
\hline Total protein & 86 & $34^{\mathrm{D}}$ & $46^{\mathrm{CD}}$ & $46^{\mathrm{CD}}$ & $67^{\mathrm{BC}}$ & $71^{\mathrm{BC}}$ & $90^{\mathrm{B}}$ & $124^{\mathrm{A}}$ & 9.5 \\
PFK activity** & 55 & $\mathrm{ND}$ & $2.33^{\mathrm{B}}$ & $3.43^{\mathrm{AB}}$ & $4.21^{\mathrm{A}}$ & $4.98^{\mathrm{A}}$ & $4.31^{\mathrm{A}}$ & $4.84^{\mathrm{A}}$ & 0.505 \\
CS activity** & 42 & $\mathrm{ND}$ & $5.0^{\mathrm{B}}$ & $\mathrm{ND}$ & $9.7^{\mathrm{B}}$ & $6.1^{\mathrm{B}}$ & $11.3^{\mathrm{B}}$ & $42.5^{\mathrm{A}}$ & 2.86 \\
LPL activity** & 59 & $\mathrm{ND}$ & $0.69^{\mathrm{C}}$ & $1.05^{\mathrm{AB}}$ & $1.10^{\mathrm{AB}}$ & $1.04^{\mathrm{AB}}$ & $0.88^{\mathrm{BC}}$ & $1.24^{\mathrm{A}}$ & 0.106 \\
\hline
\end{tabular}

A,B,C,D Mean values within a row with different superscript letters differ significantly $(P<0.05)$.

* SEM calculated for five animals.

** PFK: phosphofructokinase, CS: citrate synthase, LPL: lipoprotein lipase.

Table II. Developmental changes in total DNA contents ( $\mu \mathrm{g}$ per $\mathrm{g}$ fresh tissue) and in glucose transporter (GLUT1 and GLUT4) protein contents (arbitrary units per mg of membrane protein and per $\mu \mathrm{g}$ DNA) in the bovine heart during foetal life.

\begin{tabular}{|c|c|c|c|c|c|c|c|c|c|c|}
\hline Age in months (m) & Number & 3 & 4 & 5 & 6 & 7 & 8 & 8.5 & 0.5 & SEM $^{*}$ \\
\hline before or after birth & of animals & & & post c & concept & tion & & & after birtl & \\
\hline Number of animals & & 9 to 15 & 17 to 18 & 10 to 11 & 12 & 10 & 4 & 14 & 5 to 6 & \\
\hline DNA content & 82 & $5419^{\mathrm{A}}$ & $5019^{\mathrm{A}}$ & $5332^{\mathrm{A}}$ & $4545^{\mathrm{A}}$ & $4812^{\mathrm{A}}$ & $5135^{\mathrm{A}}$ & $3477^{\mathrm{B}}$ & $3332^{\mathrm{B}}$ & 431.5 \\
\hline Protein in membranes & 90 & $6.5^{\mathrm{CD}}$ & $11.8^{\mathrm{AB}}$ & $9.95^{\mathrm{BC}}$ & $14.1^{\mathrm{A}}$ & $11.4^{\mathrm{AB}}$ & $8.1^{\mathrm{BCD}}$ & $9.9^{\mathrm{BC}}$ & $9.0^{\mathrm{BCD}}$ & 1.17 \\
\hline $\begin{array}{l}\text { GLUT1 content per mg } \\
\text { of membrane protein }\end{array}$ & 90 & $4815^{\mathrm{A}}$ & $1338^{\mathrm{BC}}$ & $1049^{\mathrm{BC}}$ & $583^{\mathrm{C}}$ & $500^{\mathrm{C}}$ & $1409^{\mathrm{BC}}$ & $1077^{\mathrm{BC}}$ & $498^{C}$ & 526.6 \\
\hline $\begin{array}{l}\text { GLUT1 content } \\
\text { per } \mu \mathrm{g} \text { DNA }\end{array}$ & 82 & $6.27^{\mathrm{A}}$ & $3.30^{\mathrm{B}}$ & $1.95^{\mathrm{B}}$ & $1.73^{\mathrm{B}}$ & $1.13^{\mathrm{B}}$ & $2.25^{\mathrm{B}}$ & $3.37^{\mathrm{B}}$ & $1.27^{\mathrm{B}}$ & 0.887 \\
\hline $\begin{array}{l}\text { GLUT4 content per mg } \\
\text { of membrane protein }\end{array}$ & 89 & $4601^{\mathrm{B}}$ & $2640^{\mathrm{B}}$ & $3952^{\mathrm{B}}$ & $4158^{\mathrm{B}}$ & $5021^{B}$ & $9942^{\mathrm{A}}$ & $8399^{\mathrm{A}}$ & $9902^{\mathrm{A}}$ & 978.5 \\
\hline $\begin{array}{l}\text { GLUT4 content } \\
\text { per } \mu \mathrm{g} \text { DNA }\end{array}$ & 81 & $6.5^{\mathrm{C}}$ & $6.6^{\mathrm{C}}$ & $7.6^{\mathrm{C}}$ & $13.0^{\mathrm{B}}$ & $11.8^{\mathrm{B}}$ & $15.9^{\mathrm{B}}$ & $35.9^{\mathrm{A}}$ & $26.0^{\mathrm{AB}}$ & 10.60 \\
\hline
\end{tabular}

A,B,C,D Mean values within a row with different superscript letters differ significantly $(P<0.05)$.

* SEM calculated for five animals.

The two glycolytic enzyme activities gradually increased throughout gestation to attain a plateau from 6 months of age for PFK (Tab. I) and from 8.5 months of age for LDH (Fig. 2).

Similarly, ICDH activity was the lowest in 3 to 7-month-old foetuses, intermediate in 8 and 8.5-month-old foetuses and the highest in young calves (Fig. 2). In the same way, CS and LPL activities were higher in young calves than in foetuses. It is thus noteworthy that the level of oxida- tive enzymes (ICDH, CS, LPL) increased especially around birth (Tab. I and Fig. 2).

Unlike metabolic enzyme activities, the number of total insulin and IGF I binding sites decreased regularly throughout ontogenesis to reach the lowest levels either for 8.5-month-old foetuses (as for insulin binding sites) or for young calves (as for IGF I binding sites) (Fig. 2).

GLUT1 and GLUT4 protein contents before birth were analysed by western blot analysis using microsomal membranes 

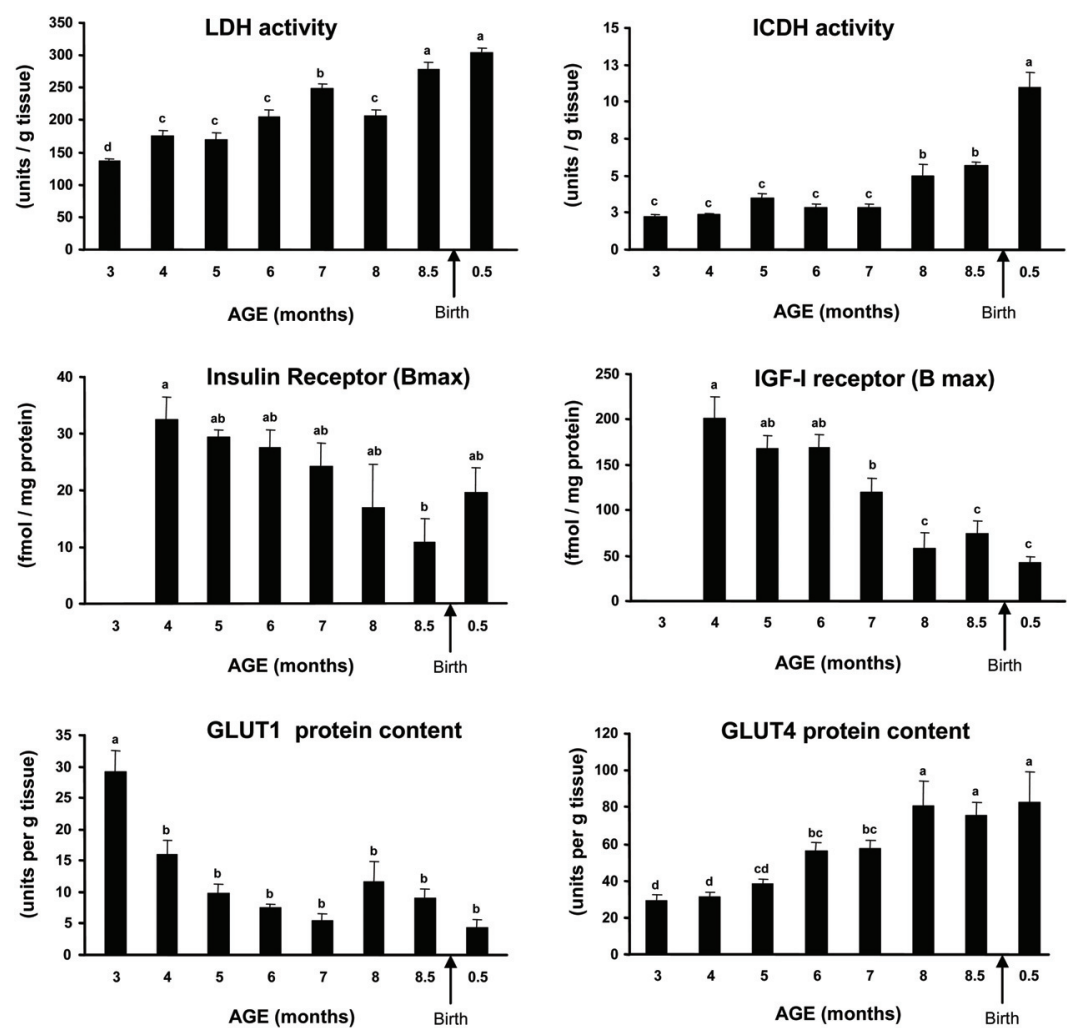

Figure 2. Developmental changes (i) in lactate (LDH) and isocitrate dehydrogenase (ICDH) activities, (ii) in insulin and IGF-I binding sites, and (iii) in glucose transporter (GLUT1 and GLUT4) protein contents in the heart throughout foetal development. Analyses were performed on 89 to 90 samples for GLUT1 and GLUT4, on 73 samples for LDH and ICDH activities and on 42 to 46 samples for insulin and IGF-I binding sites. The results are indicated as means \pm standard errors (SE) per $g$ fresh tissue for glucose transporters and enzyme activities and in fmoles per mg membrane protein for hormone binding sites. Means with different superscript letters differ significantly $(P<0.05)$.

as shown in a representative experiment (Fig. 3). Samples of rat heart and bovine brain were used as positive controls (Fig. 3). GLUT1 protein content, expressed per mg of membrane protein, was higher in 3-month-old foetuses than in any other age group $(+250 \%$ on average, $P<$ $0.05)$. Furthermore, it decreased significantly from 4 to 7 months, increased at 8 months of age and decreased thereafter although these latter differences were not significant. By contrast, GLUT4 protein contents expressed per mg of membrane protein were higher in old foetuses (from 8 months of age) and in young calves than in 2 to 7 -month-old foetuses $(+130 \%, P<$ 0.05) (Tab. II). Similar results were obtained when data were expressed per $g$ tissue wet weight taking differences in yields from crude membrane preparations into account (Fig. 2). The results are quite similar when expressed per $\mu \mathrm{g}$ DNA (Tab. II). 


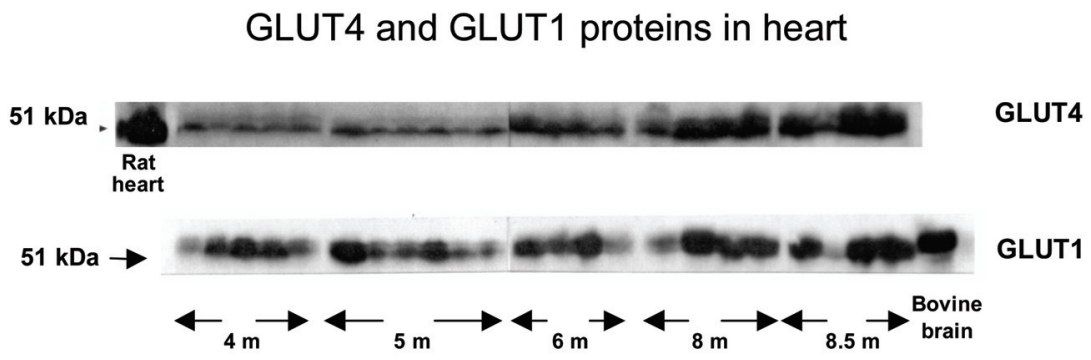

\section{GLUT4 protein in perirenal adipose tissue}

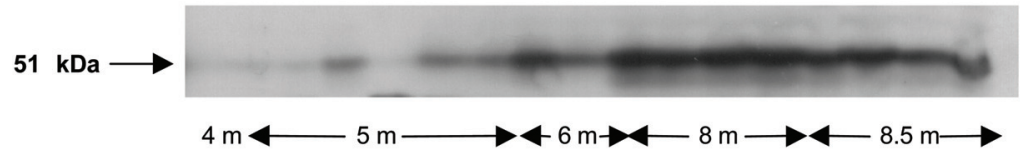

GLUT 4

Figure 3. Representative western-blot analysis between 4 and 8.5 months of foetal development (i) of glucose transporter (GLUT4 and GLUT1) proteins in crude membranes of bovine heart and (ii) of GLUT4 protein in crude membranes of bovine perirenal adipose tissue. Not all animals or stages are shown. This representative experiment shows the increase in GLUT4 expression before birth in the heart and adipose tissue.

\subsection{Developmental changes in biochemical and metabolic characteristics of the perirenal adipose tissue}

The weight of the perirenal adipose tissue represented 0.2 to $0.4 \%$ of body weight during foetal life but $0.14 \%$ in young calves.

Total protein contents in homogenates were significantly higher in young calves than in foetuses (58 vs. 20 to $40 \mathrm{mg}$ per $\mathrm{g}$ fresh tissue $P<0.05)$. Unlike the heart, protein contents in microsomal membranes, which were used for glucose transporter studies, were higher in older foetuses (from 6 months of age) and young calves than in young foetuses of 2 to 5 months of age (6.6 to 9.2 vs. 1.8 to 3.1 $\mathrm{mg} / \mathrm{g}$ tissue, $P<0.05$ ) (Tab. III). DNA content varied during foetal life but its variation did not seem to be related to age per se (Tab. III). Due to the large variations in microsomal protein and DNA protein contents, we preferred to express the results of GLUT1 and GLUT4 protein expression only per g wet tissue (Fig. 4), which also facilitated the comparison with the situation in the heart (Fig. 2). GLUT1 and GLUT4 protein expression per g wet tissue were, however, similar to those observed on the gels as shown for GLUT4 before birth (Fig. 3).

GLUT1 protein contents were the lowest at 3-4 months of age and the highest at 7 months of age, the difference being 37fold between these two extreme ages. They tended to decrease thereafter (Fig. 4).

GLUT4 protein content was undetectable until 5 months of age. It was the highest at 8 months of age and sharply decreased thereafter (Fig. 4).

CS activity gradually increased during foetal life in adipose tissue, but sharply decreased after birth (Tab. III). This indicates 
that adipose tissue had a high mitochondrial activity before birth.

LPL activity sharply increased during foetal life to reach a maximum at 67 months of gestation and markedly decreased thereafter (Fig. 4).

\section{DISCUSSION}

A great deal of research has been conducted to study the developmental expression of glucose transporters in relation with tissue differentiation. A switch from GLUT1 to GLUT4 expression occurs around birth [11] and after the suckling period in rats on a high-carbohydrate diet [28]. However, some species-specific or tissue-specific developmental regulation of GLUT1 and GLUT4 expression has been previously demonstrated, but mostly in laboratory rodents or in in vitro systems. The present study is the first of its kind to describe in vivo developmental regulation of expression of GLUT1 and GLUT4 glucose transporters in the bovine foetus. It is of particular interest not only for cattle but also for humans since both are earlymaturing species for muscle development [13] and have similar gestation periods. Our results indicate that the timing of the changes in GLUT1 and GLUT4 expression is clearly different in the heart and the perirenal adipose tissue, and that it follows the differentiation pattern of each tissue.

\subsection{Ontogenesis of glucose transporters}

Glucose is the primary substrate for foetal metabolism, but, unlike humans and monkeys, in ruminants, the glucose level is much lower in foetal arterial plasma than in maternal arterial plasma [29]. Glucose use by foetal tissues depends on the potential of the tissues to take up circulating glucose from plasma. To assess this potential, we determined GLUT1 and
GLUT4 protein contents in crude membranes from heart and adipose tissue of bovine foetuses. The two centrifugation steps performed to prepare crude membranes were aimed at removing nuclei and cytosol that do not contain glucose transporters. The latter are known to be localised in internal and peripheral membranes. Changes in GLUT1 protein content in the rat heart were shown to be similar in crude membranes by western-blot analysis and in cryostat sections by immunofluorescence [30], thus validating our technical approach. However, partial and variable recovery of internal and peripheral membranes in our subcellular fractions depending on the tissue structure and toughness (which may affect the initial homogenisation step) cannot be excluded. This is the reason why the results are expressed per $\mathrm{g}$ fresh tissue. The tissue structure obviously differs between heart and adipose tissue, but also between ages and individuals (as shown for instance by the variability in DNA levels in adipose tissue). It indeed depends on the tissue differentiation stage across ages and between breeds. In this way, working with different genotypes has probably affected the results by creating a greater biological variability, but the results may be more representative of the situation in the bovine species as a whole.

The high expression of GLUT1 glucose transporters in peripheral tissues during foetal and early neonatal life is likely to explain the high rate of glucose uptake by foetal tissues which have been described for the rat foetal heart [31]. GLUT1 is already highly expressed in bovine oocytes [32] suggesting that foetal cells are able to take up glucose and use it as an energy source from the earliest stages. As in cattle (present study), GLUT1 expression has also been shown to be maximal in early foetal life and to decrease steadily throughout gestation in the heart and skeletal muscle of the chicken [33]. Some species-specific regulation has, however, 
Table III. Developmental changes in total DNA content ( $\mu \mathrm{g}$ per $\mathrm{g}$ fresh tissue), in total and microsomal protein content ( $\mathrm{mg}$ per $\mathrm{g}$ fresh tissue) in bovine adipose tissue during foetal life.

\begin{tabular}{lccccccccccc}
\hline $\begin{array}{l}\text { Age in months (m) } \\
\text { before or after birth }\end{array}$ & $\begin{array}{c}\text { Number of } \\
\text { animals }\end{array}$ & 3 & 4 & 5 & 6 & 7 & 8 & 8.5 & $\begin{array}{c}0.5 \\
\text { after birth }\end{array}$ \\
\hline Number of animals & \multicolumn{1}{c}{12} & 14 to 21 & 11 & 10 & 10 & 4 & 14 & 5 to 6 & \\
\hline Total protein in tissue & 81 & $22.3^{\mathrm{C}}$ & $22.0^{\mathrm{C}}$ & $19.5^{\mathrm{C}}$ & $36.2^{\mathrm{B}}$ & $40.3^{\mathrm{B}}$ & $21.9^{\mathrm{C}}$ & $27.5^{\mathrm{C}}$ & $57.8^{\mathrm{A}}$ & 3.41 \\
Protein in membranes & 81 & $3.15^{\mathrm{C}}$ & $1.76^{\mathrm{C}}$ & $3.10^{\mathrm{C}}$ & $6.62^{\mathrm{B}}$ & $8.52^{\mathrm{AB}}$ & $8.29^{\mathrm{AB}}$ & $7.29^{\mathrm{B}}$ & $9.32^{\mathrm{A}}$ & 0.686 \\
DNA content & 87 & $4033^{\mathrm{A}}$ & $2734^{\mathrm{C}}$ & $3536^{\mathrm{AB}}$ & $3159^{\mathrm{BC}}$ & $2217^{\mathrm{D}}$ & $2901^{\mathrm{BC}}$ & $1859^{\mathrm{D}}$ & $2903^{\mathrm{BC}}$ & 230.3 \\
CS activity** & 58 & ND & $1.3^{\mathrm{D}}$ & $3.4^{\mathrm{D}}$ & $11.1^{\mathrm{C}}$ & $16.1^{\mathrm{B}}$ & $17.1^{\mathrm{B}}$ & $23.1^{\mathrm{A}}$ & $8.6^{\mathrm{C}}$ & 1.48 \\
\hline
\end{tabular}

A,B,C,D Mean values within a row with different superscript letters differ significantly $(P<0.05)$.

* SEM calculated for five animals.

** CS: citrate synthase.
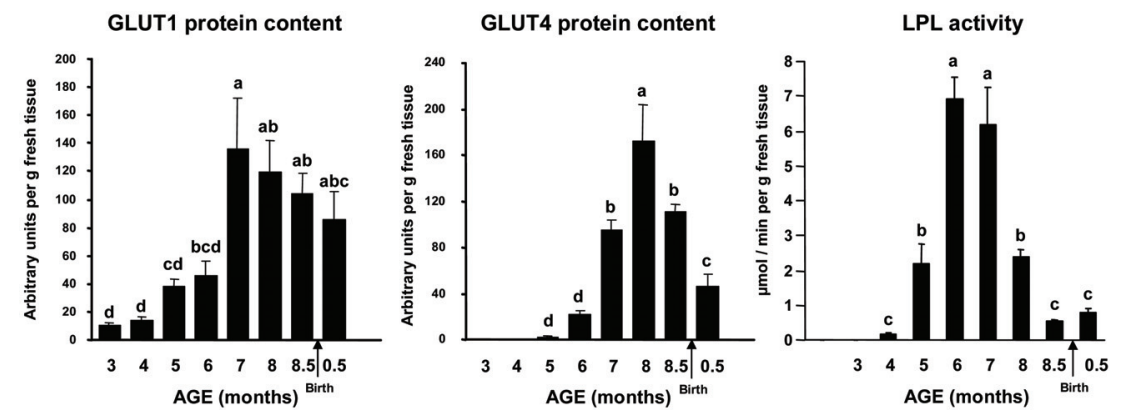

Figure 4. Developmental changes in glucose transporter (GLUT1 and GLUT4) protein contents as well as in lipoprotein lipase (LPL) activity in bovine perirenal adipose tissue throughout foetal development. GLUT1 and GLUT4 protein content and LPL activity were analysed on 81 and 57 samples respectively. The results are indicated as means \pm standard errors (SE) per $\mathrm{g}$ fresh tissue. Means with different superscript letters differ significantly $(P<0.05)$.

been demonstrated: GLUT1 expression at both the protein and mRNA levels is indeed shown to decrease after birth in the rat heart [11] and in the brain, lung, liver and kidney of rodents [34-36], whereas the GLUT1 level does not change in the skeletal muscle and adipose tissue of Holstein male calves from birth to 12 months of age [37]. Our study confirmed that birth is not associated with major and statistically significant changes in GLUT1 expression in either heart or adipose tissue of cattle.

Whereas GLUT1 expression was significantly decreased at early stages of foetal growth (between 3 and 4 months of age) in the bovine heart, it was increased in adi- pose tissue between 6 and 7 months (highly significant) but also in the heart between 7 and 8 months of foetal age (not significant). This is clearly a tissue-specific regulation. The change in GLUT1 expression in the heart was concomitant with an inverse variation in LDH activity both at the earliest stage and at 8 months of foetal growth. These data suggest that the heart converts pyruvate into lactate more efficiently when LDH activity is high, hence the lower need for glucose as an energy source. This fits well with the significantly decreased expression of GLUT1 level at the beginning of foetal life, and with the additional decrease from 8 months onwards. 
The increase in GLUT1 expression in adipose tissue is concomitant with an increase in CS activity which suggests a higher metabolic activity of adipose tissue and hence higher energy needs. The high mitochondrial activity indicates that adipose tissue is brown before birth, as previously described in cattle [38].

Bovine GLUT4 expression was first detected at the mRNA level in blastocysts whereas other glucose transporters were detected earlier [32]. GLUT4 mRNA was previously detected in the rat heart [11] and in the mouse heart [12] during foetal life. Induction of GLUT4 expression was observed in brown adipose tissue, heart and skeletal muscle before birth in the rat which agrees with our results in cattle. More precisely, in the rat heart, GLUT4 expression increases at 21 days of gestation at both protein and mRNA levels compared to the ages of 19 and 20 days [11]. Our results were also in agreement with those of Postic et al. [28] who observed high levels of GLUT4 expression in brown adipose tissue during foetal life, but with low levels at birth.

The low, but detectable expression of GLUT4 during foetal life compared to postnatal life, may explain, at least in part, why insulin causes stimulation of glucose uptake before birth as demonstrated in the foetal rat heart [31]. In the present study, the higher expression of GLUT4 from 8 months of foetal age was concomitant with lower plasma glucose levels in the foetus, suggesting that insulin stimulation of glucose uptake through GLUT4 does occur. However, unlike in cattle (present study) and rodents $[11,28]$, GLUT4 protein and mRNA appear to be absent from the chick heart and skeletal muscle [33], which may be explained either by differences in the sensitivity of the techniques used or by differences in the biological maturity at birth between the different species [13].
Other data available in the literature indicate that GLUT4 expression is also altered during postnatal life depending on nutritional changes. The expression of GLUT4 in muscles and adipose tissues increases at weaning in the rat [28] and in the pig [39], but not in cattle [40]. This may be explained by the fact that the fatrich diet of the suckled rat or the suckled pig is replaced by a carbohydrate-rich diet, whereas fat and carbohydrates of the calf milk replacer are replaced by volatile fatty acids originating from food fermentation by micro-organisms present in the rumen of herbivores from weaning onwards $[8,41]$.

However, besides changes in nutrition, and unlike observations in rats [11, 28], GLUT4 levels decrease gradually in bovine skeletal muscle and subcutaneous adipose tissue to reach, at 12 months of age, $40 \%$ of the levels observed at birth [37]. This may be related to a general decrease in muscle metabolic activity with increasing age in young cattle as described by quantifying in vivo hindlimb energy expenditure [42] or muscle oxidative capacity [43].

Some authors have suggested different molecular mechanisms to explain the changes in GLUT1 and GLUT4 expression with increasing age: whereas GLUT1 repression seems to be at the pretranslational level, GLUT4 induction is dependent on translational or post-translational activation [11]. More recent research has supplied different molecular hypotheses to explain the regulation of glucose transporter expression. In the first model related to GLUT1, MyoD activation during myogenesis causes the down-regulation of Sp1, an activator of GLUT1 expression, which contributes to the repression of GLUT1 gene transcription and hence expression [44]. Furthermore, Sp3 proteins inhibit GLUT1 gene transcription and this is dominant over the stimulatory activity of Sp1 on GLUT1 expression. 
The Sp3 protein is up-regulated early after the induction of IGFII-dependant myogenesis. Forced MyoD expression also increases the $\mathrm{Sp} 3 / \mathrm{Sp} 1$ ratio thereby decreasing GLUT1 expression [45]. In the second model related to GLUT4, a tripartite co-operation between MyoD, myocyte enhancer factor-2 (MEF2) and the thyroid hormone receptor (TRalpha1) promotes over-expression of GLUT4 in the skeletal muscle and heart by transcriptional activation of its gene [46].

\subsection{Overall differentiation of the heart and adipose tissue}

Ontogenesis of tissues has been described as having temporally distinct phases. In muscles [13], the first step is proliferation of myoblasts which occurs during the first two trimesters of gestation in cattle. Three generations of myoblasts have been described in skeletal muscles. They appear at about 60, 90 and 110 days post-conception (dpc), respectively, in cattle [47] and man [48] both of which having a similar length of gestation. The last trimester of gestation is characterised by the metabolic and contractile differentiation of muscle fibres. Thus, humans and cattle have similar degrees of maturity at birth at the skeletal muscle differentiation level but this probably also holds for heart differentiation since mitochondrial gene expression and/or enzyme changes look similar in the hearts of humans [49] and cattle [50]. In particular, citrate synthase activity increases throughout development in bovine and human hearts as observed in this study, and two other enzymes involved in fat metabolism (LPL, ICDH) follow the same pattern of expression. The activity of these three enzymes markedly increases at birth when a switch from carbohydrates to fats as main energy source occurs. By contrast, the activity of the key enzymes involved in glucose utilisation (PFK, LDH) and GLUT4 expression increase sequen- tially before birth (from 6 months of age onwards): PFK, LDH and then GLUT4.

In cattle, IGF-I, IGF-II and insulin receptor concentrations were shown to decrease throughout foetal development from 3-5 months of age onwards in both skeletal muscle $[51,52]$ and the heart (this study for IGF-I and insulin receptors only). Assuming a similar trend for the hormonal status in humans and cattle i.e. an increase in IGF-I levels throughout gestation [4] and taking into account the increase in IGF-II plasma levels with increasing age in foetal cattle [53], IGF-I, IGF-II and insulin receptor levels would be low at those stages where IGF-I and placental GH levels in pregnant females and IGF-I levels in foetuses are the highest [4], when foetal glucose level is the lowest and when foetal GLUT4 expression increases (present study). Furthermore, other in vitro studies with cultured cells from the rat hindlimb during differentiation have shown that GLUT1 is abundant in myoblasts, whereas GLUT4 is expressed in spontaneously contracting myotubes but absent in myoblasts [10]. Our in vivo results in the heart fit well with these in vitro observations. Taken together, these results suggest that the development of some players of the insulin-glucose axis (namely IGF-I and insulin receptors, GLUT1 and GLUT4) follow similar patterns in cardiac and skeletal muscles in relation with the hormonal and metabolic changes that occur during gestation.

The adipose tissue differentiation programme is characterised by several differentiation steps [54]. The mRNA expression of GLUT4 and other lipogenic genes was also shown to be coordinated in brown adipose tissue in in vivo studies [55] as we observed in this study with LPL. LPL activity, which is an early marker of differentiation, was shown to gradually increase and thereafter to decrease during in vitro brown adipose tissue differentiation [56]. In cultured adipose cells, GLUT4 protein 
level increases at least 16-fold during the differentiation period whereas the amount of GLUT1 protein gradually decreases to undetectable levels [57]. All these changes agree with our in vivo results, except that we observed significant GLUT1 protein levels and GLUT4 protein contents decreased rapidly in our study unlike in vitro studies [57].

These apparent discrepancies may be explained on the one hand by the wellknown differences between in vivo and in vitro systems, and, on the other hand, by the transition of brown adipose tissue to white adipose tissue which occurs in vivo in ruminant animals. This transition has been previously described in vivo in the goat [58]. A marked decrease in uncoupling protein expression and in a mitochondrial enzyme (cytochrome- $c$ oxidase) activity has indeed been observed from birth onwards [58], in agreement with our observation of a decrease in CS activity from old foetuses to new born calves. However, the mean GLUT4 expression level was not found to decrease after birth in the calf [37] and in the goat [58] despite large variations of GLUT4 expression during the neonatal period [58]. This is associated with the fact that GLUT4 is expressed in all insulinsensitive tissues including both brown and white adipose tissues. It is thus likely that the neonatal period may generate transient GLUT4 down-regulation between old foetuses and the newborn calf as indeed observed at the mRNA level in the rat adipose tissue [28]. Similarly, the transition of brown adipose tissue to white adipose tissue occurs at different rates depending on the species, but does not seem to be faster in goats than in other ruminants [58]. It may still be incomplete in our 2-week-old calves, which could explain in part why GLUT1 expression is still detectable in adipose tissue of new-born animals as previously observed in vivo in rats $[11,30]$ and in cattle [37]. However, the GLUT1 protein level remains constant in brown adipose tissue after birth in cattle [37] while it decreases in rats $[11,30]$ but this decrease is markedly reduced by hypothyroidism [30]. It is also noteworthy that adipose tissue differentiation is likely to be regulated by IGF I [55] as for the heart.

In summary, the present study has brought a clear picture of some important steps which characterise cardiac and brown adipose tissue differentiation. This might have important implications for both farm animals and human beings. In doublemuscled cattle (which are characterised by muscle hypertrophy and lower fat depots), an enhanced insulin action on glucose transport rate in calves [59], a higher expression of the growth hormone receptor (which regulates IGF I and IGF II expression) [60] and a higher level of a specific IGF-II transcript in skeletal muscles at the end of gestation were observed compared to normal animals. In humans, insulin resistance in subjects born with intrauterine growth retardation is associated with impaired GLUT4 expression at the mRNA level in muscle and adipose tissue [61]. Further studies are needed to understand the major molecular factors regulating the important targets of the insulin/IGF/glucose axis studied here, and at which critical steps those factors act, with the ultimate objective of controlling body composition and/or metabolic diseases irrespective of the species.

\section{ACKNOWLEDGEMENTS}

The authors thank the INRA staff at the experimental farm and at the abattoir for animal management and slaughtering. C. Delavaud and N. Guivier are also thanked for their excellent technical contribution.

\section{REFERENCES}

[1] Baker DJP. Intrauterine programming of coronary heart disease and stroke. Acta Paediatr Suppl 1997, 423: 178-182. 
[2] Hocquette JF, Ortigues-Marty I, Vermorel M. Manipulation of tissue energy metabolism in meat-producing ruminants. Asian Aust $\mathrm{J}$ Anim Sci 2001, 14: 720-732.

[3] Wu G, Bazer FW, Cudd TA, Meininger CJ, Spencer TE. Maternal nutrition and fetal development. J Nutr 2004, 134: 2169-2172.

[4] Jensen RB, Chellakooty M, Vielwerth S, Vaag A, Larsen T, Greisen G, Skakkebaek NE, Scheike T, Juul A. Intrauterine growth retardation and consequences for endocrine and cardiovascular diseases in adult life: does insulin-like growth factor-I play a role? Horm Res 2003, 60: Suppl 3, 136-148.

[5] Robinson SM, Barker DJ. Coronary heart disease: a disorder of growth. Proc Nutr Soc 2002, 61: 537-542.

[6] Ryder JW, Gilbert M, Zierath JR. Skeletal muscle and insulin sensitivity: pathophysiological alterations. Front Biosci 2001, 6: D154-163.

[7] Ozanne SE, Hales CN. Early programming of glucose-insulin metabolism. Trends Endocrinol Metab. 2002, 13: 368-373.

[8] Hocquette JF, Abe H. Facilitative glucose transporters in livestock species. Reprod Nutr Dev 2000, 40: 517-533.

[9] Watson RT, Pessin JE. Intracellular organization of insulin signaling and GLUT4 translocation. Recent Prog Horm Res 2001, 56: 175-193.

[10] Guillet-Deniau I, Leturque A, Girard J. Expression and cellular localization of glucose transporters (GLUT1, GLUT3, GLUT4) during differentiation of myogenic cells isolated from rat foetuses. J Cell Sci 1994, 107: 487-496.

[11] Santalucia T, Camps M, Castello A, Munoz P, Nuel A, Testar X, Palacin M, Zorzano A. Developmental regulation of GLUT-1 (erythroid/Hep G2) and GLUT-4 (muscle/fat) glucose transporter expression in rat heart, skeletal muscle, and brown adipose tissue. Endocrinology 1992, 130: 837-846.

[12] Vannucci SJ, Rutherford T, Wilkie MB, Simpson IA, Lauder JM. Prenatal expression of the GLUT4 glucose transporter in the mouse. Dev Neurosci 2000, 22: 274-282.

[13] Picard B, Lefaucheur L, Berri C, Duclos M. Muscle fibre ontogenesis in farm animal species. Reprod Nutr Dev 2002, 42: 415431.

[14] Sasaki SI. Mechanism of insulin action on glucose metabolism in ruminants. Anim Sci J 2002, 73: 423-433.
[15] Hocquette JF, Bornes F, Balage M, Ferre P, Grizard J, Vermorel M. Glucose-transporter (GLUT4) protein content in oxidative and glycolytic skeletal muscles from calf and goat. Biochem J 1995, 305: 465-470.

[16] Abe H, Morimatsu M, Nikami H, Miyashige T, Saito M. Molecular cloning and mRNA expression of the bovine insulin-responsive glucose transporter (GLUT4). J Anim Sci 1997, 75: 182-188.

[17] James DE, Strube M, Mueckler M. Molecular cloning and characterization of an insulin-regulatable glucose transporter. Nature 1989, 338: 83-87.

[18] Hocquette JF, Bas P, Bauchart D, Vermorel M, Geay Y. Fat partitioning and biochemical characteristics of fatty tissues in relation to plasma metabolites and hormones in normal and double-muscled young growing bulls. Comp Biochem Phys A 1999, 122: 127-138. Erratum in Comp Biochem Phys A, 1999, 123: 311-312.

[19] Bradford MM. A rapid and sensitive method for the quantitation of microgram quantities of protein utilizing the principle of proteindye binding. Anal Biochem 1976, 72: 248254.

[20] Ortigues-Marty I, Hocquette JF, Bertrand G, Martineau C, Vermorel M, Toullec R. The incorporation of solubilized wheat proteins in milk replacers for veal calves: effects on growth performance and muscle oxidative capacity. Reprod Nutr Dev 2003, 43: 57-76.

[21] Cassar-Malek I, Hocquette JF, Jurie C, Listrat A, Jailler R. Bauchart D, Briand Y, Picard B. Muscle-specific metabolic, histochemical and biochemical responses to a nutritionally induced discontinuous growth path. Anim Sci 2004, 204: 79-59

[22] Hocquette JF, Graulet B, Olivecrona T. Lipoprotein lipase activity and mRNA levels in bovine tissues. Comp Biochem Phys B 1998, 121: 85-96.

[23] Boge A, Sauerwein H, Meyer HHD. An enzyme immunoreceptor assay for the quantitation of insulin-like growth factor-I and insulin receptors in bovine muscle tissue. Anal Biochem 1994, 216: 406-412.

[24] Einarson B. Subunit composition of bovine muscle acetylcholine receptor. Biochemistry 1982, 21: 5295-5303.

[25] Scatchard G. The attractions of proteins for small molecules and ions. Ann NY Acad Sci 1949, 51: 660-672.

[26] Munson PJ, Rodbard D. Ligand: a versatile computerized approach for characterization 
of ligand-binding systems. Anal Biochem. 1980, 107: 220-239.

[27] SAS. SAS/STAT Guide for Personal Computers. Cary, NC, USA, SAS Inst Inc, 1996.

[28] Postic C, Leturque A, Printz RL, Maulard P, Loizeau M, Granner DK, Girard J. Development and regulation of glucose transporter and hexokinase expression in rat. Am J Physiol 1994, 266: E548-59.

[29] Père MC. Materno-foetal exchanges and utilisation of nutrients by the foetus: comparison between species. Reprod Nutr Dev 2003, 43: $1-15$.

[30] Castello A, Rodriguez-Manzaneque JC, Camps M, Perez-Castillo A, Testar X, Palacin M, Santos A, Zorzano A. Perinatal hypothyroidism impairs the normal transition of GLUT4 and GLUT1 glucose transporters from fetal to neonatal levels in heart and brown adipose tissue. Evidence for tissue-specific regulation of GLUT4 expression by thyroid hormone. J Biol Chem 1994, 269: 5905-5912.

[31] Clark CM Jr. Carbohydrate metabolism in the isolated fetal rat heart. Am J Physiol 1971, 220: 583-588.

[32] Augustin R, Pocar P, Navarrete-Santos A, Wrenzycki C, Gandolfi F, Niemann H, Fischer B. Glucose transporter expression is developmentally regulated in in vitro derived bovine preimplantation embryos. Mol Reprod Dev 2001, 60: 370-376.

[33] Carver FM, Shibley IA Jr, Pennington JS, Pennington SN. Differential expression of glucose transporters during chick embryogenesis. Cell Mol Life Sci 2001, 58: 645-652.

[34] Asano T, Shibasaki Y, Kasuga M, Kanazawa Y, Takaku F, Akanuma Y, Oka Y. Cloning of a rabbit brain glucose transporter cDNA and alteration of glucose transporter mRNA during tissue development. Biochem Biophys Res Commun 1988, 154: 1204-1211.

[35] Sivitz W, DeSautel S, Walker PS, Pessin JE. Regulation of the glucose transporter in developing rat brain. Endocrinology 1989, 124: 1875-1880.

[36] Sadiq F, Holtzclaw L, Chundu K, Muzaffar A, Devaskar S. The ontogeny of the rabbit brain glucose transporter. Endocrinology 1990, 126: 2417-2424. Erratum in: Endocrinology 1994, 135: 1583.

[37] Abe H, Kawakita Y, Hodate K, Saito M. Postnatal development of glucose transporter proteins in bovine skeletal muscle and adi- pose tissue. J Vet Med Sci 2001, 63: 10711075.

[38] Robelin J, Casteilla L. Différentiation, croissance et développement du tissu adipeux. INRA Prod Anim 1990, 3: 243-252

[39] Hocquette JF, Castiglia-Delavaud C, Le Dividich J, Vermorel M. Glucose transporter (GLUT4) expression in muscles and adipose tissues in differently affected by changes in nutrition at weaning in the pig and in the calf. The 8th Animal Science Congress of the Asian-Australian Association of Animal Production Societies, Tokyo (Japon), 13-18 October 1996.

[40] Hocquette JF, Castiglia-Delavaud C, Graulet B, Ferré P, Picard B, Vermorel M. Weaning marginally affects glucose transporter (GLUT4) expression in muscles and adipose tissues in the calf. Brit J Nutr 1997, 78: 251-271.

[41] Hocquette JF, Bauchart D. Intestinal absorption, blood transport and hepatic and muscle metabolism of fatty acids in preruminant and ruminant animals. Reprod Nutr Dev 1999, 39: 27-48.

[42] Bauchart D, Ortigues I, Hocquette JF, Gruffat D, Durand D. Energy and fat metabolism of the liver, the digestive tract and muscles: transport, processing, energy consumption, fixation by tissues. In: Veal, Perspectives to the year 2000, the French Federation of Veal Producers (Ed), Le Mans, Presse de Jouve, 1996, p 255-290.

[43] Piot C, Veerkamp JH, Bauchart D, Hocquette JF. Contribution of mitochondria and peroxisomes to palmitate oxidation in rat and bovine tissues. Comp Biochem Phys B 1998, 121: 69-78.

[44] Vinals F, Fandos C, Santalucia T, Ferre J, Testar X, Palacin M, Zorzano A. Myogenesis and MyoD down-regulate Sp1. A mechanism for the repression of GLUT1 during muscle cell differentiation. J Biol Chem 1997, 272: 12913-12921.

[45] Fandos C, Sanchez-Feutrie M, Santalucia T, Vinals F, Cadefau J, Guma A, Cusso R, Kaliman P, Canicio J, Palacin M, Zorzano A. GLUT1 glucose transporter gene transcription is repressed by Sp3. Evidence for a regulatory role of Sp3 during myogenesis. J Mol Biol 1999, 294: 103-119.

[46] Santalucia T, Moreno H, Palacin M, Yacoub $\mathrm{MH}$, Brand NJ, Zorzano A. A novel functional co-operation between MyoD, MEF2 and TRalpha1 is sufficient for the induction of GLUT4 gene transcription. J Mol Biol 2001, 314: 195-204. 
[47] Gagnière H, Picard B, Geay Y. Contractile differentiation of foetal cattle muscles: intermuscular variability. Reprod Nutr Dev 1999, 39: 1-19.

[48] Draeger A, Weeds AG, Fitzsimons RB. Primary, secondary and tertiary myotubes in the developing skeletal muscle: a new approach to analysis human myogenesis. J Neurol Sci 1997, 81: 19-43.

[49] Marin-Garcia J, Ananthakrishnan R, Goldenthal MJ. Heart mitochondrial DNA and enzyme changes during early human development. Mol Cell Biochem 2000, 210: 47-52.

[50] Marin-Garcia J, Ananthakrishnan R, Agrawal N, Goldenthal MJ. Mitochondrial gene expression during bovine cardiac growth and development. J Mol Cell Cardiol 1994, 26: 1029-1036.

[51] Boge A, Sauerwein H, Meyer HHD. IGF-I and insulin receptors in bovine skeletal muscle: comparisons of different developmental ages, two different genotypes and various individual muscles. Exp Clin Endocrinol Diabetes 1995, 103: 99-104.

[52] Listrat A, Jammes H, Djiane J, Geay Y, Robelin J. Characterisation and location of insulin-like-growth factor (IGF) receptors and in the foetal bovine Semitendinosus muscle. Reprod Nutr Dev 1999, 39: 467479.

[53] Listrat A, Belair L, Picard B, Boulle N, Geay Y, Djiane J, Jammes H. Insulin-like growth factor II (IGF-II) mRNA expression during skeletal muscle development of doublemuscled and normal bovine foetuses. Reprod Nutr Dev 1999, 39: 113-124.

[54] Boone C, Mourot J, Gregoire F, Remacle C. The adipose conversion process: regulation by extracellular and intracellular factors. Reprod Nutr Dev 2000, 40: 325-358.
[55] Teruel T, Valverde AM, Alvarez A, Benito M, Lorenzo M. Differentiation of rat brown adipocytes during late foetal development: role of insulin-like growth factor I. Biochem J 1995, 310: 771-776.

[56] Encke D, Ely M, Heldmaier G, Klaus S. Physiological approach to maturation of brown adipocytes in primary cell culture. Biochim Biophys Acta 1997, 1357: 339347.

[57] Hauner H, Rohrig K, Spelleken M, Liu LS, Eckel J. Development of insulin-responsive glucose uptake and GLUT4 expression in differentiating human adipocyte precursor cells. Int J Obesity 1998, 22: 448-53.

[58] Trayhurn P, Thomas MEA, Keith JS. Postnatal development of uncoupling protein, uncoupling protein mRNA, and GLUT4 in adipose tissues of goats. Am. J. Physiol 1993, 265: R676-R682.

[59] Picard B, Hocquette JF, Bornes F, Brazi S, Vermorel M, Geay Y. Muscle metabolism in normal and double muscled calves fiber characteristics and glucose transport rate. In: Aguilera JF (Ed), Energy Metabolism of Farm Animals, Granada (Spain), Consejo Superior de Investigaciones, 1994, p 97-100.

[60] Listrat A, Hocquette JF, Picard B, Ménissier F, Djiane J, Jammes H. Growth hormone receptor gene expression in skeletal muscle of normal and double-muscled bovine during foetal development. Reprod Nutr Dev 2005, 45: 393-403.

[61] Jaquet D, Vidal H, Hankard R, Czernichow P, Levy-Marchal C. Impaired regulation of glucose transporter 4 gene expression in insulin resistance associated with in utero undernutrition. J Clin Endocrinol Metab 2001, 86: 3266-3271. 